\title{
Psycho-Sociological Motivations of Civil Servants and Corruption Practices in the Cameroon Public Service: Case of the Ministries of Basic and Secondary Education
}

\author{
NDONG ELIAS \\ University of Maroua / Cameroon
}

\begin{abstract}
Summary
This work intends to study the psycho-sociological motivations of civil servants and corruption practices in the Cameroon Public Service: Corruption as well as other questions of development is an emergent problem which needs to be taken seriously. In Cameroon and particularly in the education sector, it has taken a considerable dimension. The research question which sustains this study goes thus: Do the psycho-sociological motivations of civil servants have an impact on corruption practice in the Cameroon Public Service? From enquiries carried out on 200 teachers of both the Basic and Secondary Education of the Wouri Division (Littoral Region), the results indicate that corruption practice is linked to the dissatisfaction of needs and the expectations of civil servants as well as poor working conditions. Thus a significant link between psycho-sociological motivations of civil servants and corruption practice in the Cameroon Public Service.
\end{abstract}

Keywords: motivations, psycho-sociological motivations, corruption.

DOI: $10.7176 / \mathrm{JEP} / 10-23-02$

Publication date: August $31^{\text {st }} 2019$

\section{I- CONTEXT AND STATEMENT OF PROBLEM}

The phenomenon of corruption is nowadays spread in the world. No sector of activities, no country can escape from it. One day cannot go by without one hearing people talk of corruption scandal. It has taken a considerable magnitude to the extent of becoming a set back to economies, considerably ruining the foundations of social justice. Countries of eastern, central and western Europe had been literally submerged by corruption scandal and same even consider that it represents a serious threat to economic and democratic systems.

Corruption therefore is a reality; the signing of numerous conventions to counteract it can attest (United Nations Convention against corruption, Inter American Convention against corruption, the African Union Convention for the prevention and fight against corruption).

In effect, in most developing countries particularly those categorized amongst "poor and heavily indebted countries" such as Cameroon, corruption is truly born from a socio-economic context characterized by an economic crisis which major effect had been the devaluation of CFA francs; the signing of structural adjustment agreements which impose, as underlined by the former Vice Governor of Cameroon at IMF MBOG Paul Denis (Mutations $\mathrm{n}^{\circ} 396,2$ 000):

"Some drastic measures to the government notably: the reduction of administrative expenditures, the privatization of public enterprises, the reduction of salaries at $70 \%$ from the level of 1992, the redundancy of more than $50 \%$ of state agents. Since then, the fiscal basis increased, inflation becomes galloping. The administration hardly makes provisions in material and stationery to the extent that to obtain a service, the citizen had become a customer: one had to buy papers, contribute to the purchase of ribbon, in short some stationeries and the secretary benefited from this, to tell you how much his son is sick and he needs help to buy some nivaquine tablets. And at all the slees, one will register the same complaints. At the most high level, the power of the signature will be paid for and frequent bribery for the signing of contracts. $\gg$

Within the limits of structural adjustment financing programs, Breton Wood institutions such as the World Bank and International Monetary Fund firstly fund the Education sector which is evaluated through the Human Development Indice (HDI). But corruption has taken a fearful or better alarming proportions there. For example, to enroll a child in a Cameroon Government School is henceforth negotiated at a golden price. Meanwhile, education is the domain of activities which absorbs the highest part of unemployed higher education diploma holders. One would have expected as such the example comes from there considering that they constitute a key lever of development. The corruption tentacles have encrusted there and Ayissi (2 003) talks of «the magic of corruption», because he precises «when money, sex and power impose their necessity to education and training, dunces are taken for genius, it is now left for imbeciles the merit of the exceptionally gifted, epistemological values are taken for merchant values.»

As such, from the nursery to the secondary schools, corruption has been established in all the activities. (Registration, evaluation). 
The free education announced by the Head of State during his message to the youths on February $10^{\text {th }} 2000$ and went in vigor between 2000 and 2001 remains theoretical because, a different reality is been observe when it comes to practice. It is in the secondary that the corruption cancer has taken its roots before extending its metastasis to the primary and nursery. In the Government High Schools of Douala, since several years, the official tariff of one place is fifty thousand CFA (cf. Mutations $n^{\circ} 1290,2$ 004). When the required place concerns a form one class, normally accessible through a competitive examination, the tariff goes up to 100000 francs CFA.

Evaluation is not saved. For example, obligatory oral questions up to now for obtaining Advanced Level had been eliminated because they had become «shows during which the evaluation of candidates were negotiated not in to their intellectual presentations, but following the amount of money which he had to give to the examiners for each subject.» (Ayissi, 2003).

Corruption is equally dominating in the designation process of officials in the education sector, both in the central as well as in the external services. Also, in violation of statutory and other routine dispositions in vigor, do we only find teachers who have only two years of service or even less in posts like sub director, chief of service, principal, pedagogic Inspectors etc...

The omnipresence of corruption has enriched the Cameroonian vocabulary of the neological lexis typical of the native tang which only those initiated can easily decipher the meaning: tchoko, makala pati, to literally mean baksheesh, bribe; fatten the paste, soak the beard to mean gratify the one who treats your file so that he does it with diligence and subjectivity in light with your recommendations. Civil servants have become birds of prey meanwhile they are at the nations service and, to this title, services rendered were not supposed to be coined. Their case is more and more a challenge because they are workers who, in Cameroon, are assured to perceive a monthly salary remuneration. In popular representations, civil servants enjoy from job security. But in the global production system, every worker, be he of the public or private sector, of the primary, the secondary or the tertiary, is remunerated at the end of the month. Suddenly, the phenomenon of motivation through one of its most important factors go in force: expectation.

Where comes therefore that for a service rendered, for which one had been recruited and for which one is been paid, should one demand extra remuneration again in the form of bribery? Would the needs dissatisfaction and civil servants expectations as well as their poor working conditions be the beginning of such a behavior? What therefore is the place of psycho-sociological motivations of civil servants in the practice of corruption? In other words do psycho-sociological motivations of civil servants have an impact on the corruption phenomenon?

Our study intends to answer this by searching for the causes of corruption through intrinsic and extrinsic factors of psycho-sociological motivations of civil servants. His central objective is to explain that corruption in the Cameroon Public Service is linked to the psycho-sociological motivations of civil servants. To do this, it entails:

- To show that the dissatisfaction of the primary and secondary needs of civil servants has an impact on the corruption level in the Cameroon Public Service;

- $\quad$ To put the corruption level in the Cameroon Public Service and the dissatisfaction of civil servants expectations in relationship;

- To establish a correlational link between the working conditions of Cameroon Civil Servants which are demotivating and corruption practice in the Cameroon Public Service.

\section{II- CONCEPTUAL AND THEORETICAL APPROACHES OF THE STUDY \\ Motivations}

According to Citeau and Engelhardt (1999) motivations constitute «a group of dynamic factors which orient and determine the conduct». In other words, the term motivation serves to design forces that act on an individual or in himself to push him behave in a particular manner and orientate towards an objective.

Pieron (1992) on his part defines motivation as «a psychological factor (conscious or not) predisposing the human or animal individual to accomplish certain actions or to tend towards certain goals».

Need is a determining factor of motivation which satisfaction leads to a balanced state.

\section{Needs}

Need is generally defined as «an unsatisfactory state of tension linked to a necessity (biological, psychological or sociological) existential».

«which push an individual to search for a more satisfactory balanced state» Muchielli (1999). The dissatisfaction of needs is a source of numerous behaviors amongst which is corruption.

\section{Corruption}

It is difficult to give a precise definition of corruption which warrants in all the forms, all the types and all the degrees of corruption, or which will universally admit as covering all the qualified actions of corruption in each of the jurisdictions. Never the less, the one given by the German Transparency International NGO in New Letters (2004) notably « the abuse of a public charge for personal enrichment aims » could in every case constitute the smallest common denominator, although it can still be more and more refined.

According to Nutin (1985), «For the psychologist unlike the psychological, motivation is neither, a 
biochemical state of a tissue, nor an activation of nervous cells. Studying behavior as a dynamic aspect of the entry into relationship of an individual with the world». So motivation is oftenly conceived by him «as an eruption which goes from the organism, either as an attraction which emanates the object and attracts the individual. » As such Freud's classical theories of instinct and the needs hierarchy of Maslow belong to the first category. To behave therefore is essentially a function of relationship. And, to Nutin (1985) « Motivation being the dynamic aspect of this relational function, it is in the network of these relationships itself that a psychological theory of motivation in reality must find its starting point. What renders the relationship which unites the individual to his environment dynamic, is the established fact that the living being, and the human personality, in particular is not indifferent to objects and situations with which it comes into relationship. Certain forms of contacts and interactions are preferable to others, some are searched for and even « required for the optimum functioning of the individual, some on the contrary are avoided and apparently harmful. »

To Amblard and al (1987), motivation describes the force which initiates behavior and orientate it towards a goal which the response will provide a satisfactory response to a need. The concept of motivation also represents a hypothetical build used in order to describe internal and/or external forces producing the starting, the direction, the intensity and the persistence of behavior (Roussel, 2 000).

Numerous theoretical arguments affirm that corruption reduces with salaries of public agents. Incitement theories about this show that there exists an efficiency salary easily assimilated to the hope for bribe associated to corruption able to hinder corruption. Even if efficiency salary is difficult to put in place within a budgetary restriction context due to its costly nature, incitements theory suggest that, everything being equal, an increase in salary would reduce the corruption of public agents.

Remuneration therefore appears as a fundamental element determining the psycho-sociological behavior of a civil servant challenged with a corruption situation. Chauchard (1989) affirms to this fact that remuneration as a motivation element must valorize the acknowledgment of the wage-earner, enable him to socially and professionally situate himself. As for Breton (1990), after having corresponded a longtime to the idea of a contractual indemnity defined to enable the civil servant to maintain a social rank in conformity to the required dignity of his functions; henceforth treatment is attached to the necessary due of a service rendered. This exchange aims to provide the latter his main source of cash revenue and other advantages against his availability, his skills and his performance (Redheuil, 1990). Bidias (1971), supports that the civil servant's treatment must enable him to maintain the social rank corresponding to his functions. To Marjolein Dieleman and a.l (2003), if wage-earners and their working conditions are unsatisfied (example: wage-earners cannot cover their basic needs), workers will have the tendency to search for ways and means to compensate these loop holes.

Maslow (1954) after study on human behavior from 1939 to 1943, defines a hierarchy of human needs in view to determine the levers of motivation. It goes from the principle that individuals have a complex group of exceptionally strong needs due to the fact that they determine their behaviors and can be classified in a hierarchical order. This hierarchy lies on four basic assumptions:

- $\quad$ Every human being has some needs to satisfy;

- These needs are in hierarchy;

- A superior need can only motivate if inferior needs are fulfilled;

- $\quad$ A satisfied does not engender motivation (Hellriegel, D., Slocum, J.W. and al. 1999).

Nevertheless, when a need is satisfied, another one arises and substitutes the previous one, such that individuals always struggle to satisfy some needs.

Psycho-sociological motivations of the corruption of Cameroonian civil servants can then understand themselves through unsatisfied needs. The case of housing needs is sufficiently edifying in this sense. In fact, building oneself a house is a security need so much sought for by every individual. It is as such registered in the fantasm of Cameroonian civil servants up to the point that the satisfaction of this latter constitutes a very important step in their life. But as housing priorities and general policies in matters of having access to housing evolve in opposing phase, to have lodging for a Cameroonian civil servant is not sinecure; it is an everyday battle. It is in fact what might explain the fact that after having embezzled money from state coffers, one builds his houses. From where the birth of spontaneous catchments today with houses at the incredible speed of the Eldorado's ways.

Klitgaard (1988) defines corruption in the form of an equation which puts the monopoly, discretional power and the absence of individual or collective responsibility in relationship. He states it as follows:

Monopoly + discretional power - responsibility = corruption

Monopoly can be practiced by a person, a society or a minister who arbitrarily decides on the wideness of a service without it being possible, due to the absence of transparency, to know what this individual does. To this effect, authoritative and planned economy regimes are generally most propitious fields to favour and maintain corruption because, at the head of every shackle of power and production on the socio-economic aspect, there always almost exist some leaders who apply by the fact of their monopoly, a tyrannical leadership, even essentially pathological.

Studying the behavior of the corruptor opposed to dubious agent, Jaquemet (2006) notes that from the moment 
the agent possesses a monopoly on the discretional power for which he is in charge (Klitgaard,1988), «by meaning, the corruptor otherwise finds himself in the impossibility to obtain the expected service by legal means. For the reason of these two proprieties, corruption, through the pouring of sweetener, is therefore the only means for the corruptor to obtain the benefit of service. More so, the hypothesis of the monopoly of offer engenders that the corruptor assumes the moral, real and monetary-costs linked to the instauration of the relationship of corruption alone. When a corruptor puts his procedures on motion, his enterprise will only be able to succeed if he finds an agent having decided to be corrupted considering the incitements that are offered him. A corruptor decides to engage in a corruption relationship if the expected benefit is positive. In this expression, the probability and amount of bribe results from the success of interaction between the corruptor and the agent».

Besides (Vroom, 1964) affirms that motivation at work is determined by individual convictions as concerns relationship between the effort and quality of service on one hand, and, on the other hand, the desirability of diverse results of work associated to different degrees of quality of the service. Four hypotheses according to him therefore determine the causes of the behavior of man in organizations:

- It is a combination of forces in the individual and in the environment which determine his behavior. - Individuals take decisions as regards their behavior in an organization.

- Different individuals have different needs and different goals. The employed expect several sorts of results from their work (Job security, promotions, a good salary...).

- Individuals make a choice amongst many possibilities, according to the way that they perceive that a given behavior will bring along the desired result.

In fact, expectations are an association between the action and its consequences (Vroom, 1964). It is about the believe according to which a precise behavior shall be followed by a given consequence. And, this consequence can be positive or negative. Where within the frame of our study corruption practice is nothing else than a negative consequence to entire country and a positive consequence to the civil servants; given that it provides them satisfaction.

If as much as it is true that individuals' expectations are based on their needs, their motivations and experience, it is undeniable that the results will tilt towards the direction of these latter. As such, corruption practice as effected by Cameroonian civil servants would find a justification from the moment where every individual at his duty post has well precise expectations to enable him satisfy his needs. One of the expectations of the majority of Cameroon civil servants will be salary increase for an improvement of their living conditions. They toady to work but the results do not accompany the efforts furnished. And, against all expectations instead of a revalorization of salaries they finally receive a salary decrease for two consecutive times, in 1992 and 1993, with a value of about $70 \%$, as such rendering life even more complicated.

\section{III- METHODOLOGY}

\section{A-Topic}

The present study examines the causes of corruption practice in the Cameroon Public Service. As such it aims to establish the link that exist between corruption practices and psycho-sociological motivations of civil servants. The population's choice had been effected following the theoretical consideration that «a population statistics is a group of finished or unfinished elements defined in advance and on which observations are carried out». (Grawitz, 1976). Our target population is therefore made up of all the civil servant teachers of the Ministries of Basic Education and Secondary Schools. It is characteristics of its geographical link which is the Ministry, of its gender (man or woman merged up) and the socio-economic status. We have taken our sample from there, to respond to the representative criteria. To this effect, we went down to Government Primary Schools, Government Secondary Schools, to inspectorates and even delegations to carry out our enquiries. Due to the nature of the topic treated, we assured confidentiality to the enquired in the treatment of data. Reason why, we have simply stratified civil servants of education according to their grade. Most methodologists according to Matalon (1999) agree to say that it is an evidence that the quality and the validity of results of (research) an enquiry depend on the size of the sample questioned, this generally being function of available resources: time, money, documents. These imperatives have imposed us a total number of 200 enquiries. Due to the depth of our study, we had wanted a sample representing all the grades of civil servant teachers.

\section{B- Material}

To find the motives of the birth of the corruption system in Cameroon, we submitted our topic of our sample to a questionnaire made up of four themes in direct relationship with the problem statement of the study and especially the hypotheses that she has suggested to us. It is about themes based on priority needs of Education civil servants, their expectations and their working conditions. For that we have at the same time asked closed opened and even questions preformulated. From the nominal scale in which variables are deployed, we have deemed necessary to conceive answer scales retained for the topics submitted to the enquiry. This choice seems judicious to us in the 
case where respondents' opinions will vary in a quantity of infinite modalities. The response ladder stretches on a comparison of modalities between what was supposed to be and what really is.

We have drawn questions (item) from the four main themes of the study. To respect the construction procedure of a questionnaire, we have added one of the most important items in it, the identification of the answerer and the item of general information to measure the pertinence of the problem raised or better still the dimension of the phenomenon studied. The variables in study are corruption practice and psycho-sociological motivations. As such, the practice of corruption can be observed from different indicators. We have retained four notably: embezzlement, swindle, favouritism and coining. Elsewhere, psycho-sociological motivations consist of examining the indicators susceptible of pushing an individual to act in one way or the other. The indicators observed concern needs, expectations and working conditions. Comparatively to needs, the investigation has consisted to know if priority needs of civil servants are satisfied. As concerns expectations, we have wanted to know if those of civil servants were satisfied. Working conditions equally constitute essential indicators of psychosociological motivations.

\section{IV- RESULTS}

Our study based on qualitative variables and to a nominal statistical value scale, we have used khi-two $\left(\mathrm{x}^{2}\right)$ test which, after crossing between independent variables and dependent variables, has enabled us to have contingency tables. From this test comes the calculation of contingency calculation which enables us to appreciate the strength of connection between the different variables.

*Needs

During the descriptive analysis, we noticed, through the results of the flat selection, that civil servants of education have as priority needs: to build a house, eat and drink, be in security and have comfort and that the dissatisfaction of these needs has an impact on the level of corruption in Cameroon Public Service. Consequently, to measure the link existing between the different variables and verify our research hypothesis, we have crossed the propensity of corruption practice with these needs.

- Need to build oneself a house.

The results of the table below indicate the link that exist between this modality and corruption propensity Cameroon Public Service.

Table 1: Crossing between corruption propensity and building one a house

Symmetric Measurements

\begin{tabular}{|l|l|c|c|c|c|}
\hline \multicolumn{2}{|l|}{} & Value & $\begin{array}{c}\text { Asymptomatic } \\
\text { standard error } \\
\text { (a) }\end{array}$ & Tpproximate (b) & $\begin{array}{c}\text { Approximate } \\
\text { significance }\end{array}$ \\
\hline $\begin{array}{l}\text { Nominal by } \\
\text { Nominal }\end{array}$ & $\begin{array}{l}\text { Coefficient of } \\
\text { contingency }\end{array}$ & .166 & & & .066 \\
\hline $\begin{array}{l}\text { Interval by } \\
\text { Interval }\end{array}$ & R of Pearson & .162 & .059 & 2.262 & .025 (c) \\
\hline $\begin{array}{l}\text { Ordinal by } \\
\text { Ordinal }\end{array}$ & $\begin{array}{l}\text { Correlation of } \\
\text { Spearman }\end{array}$ & .168 & .062 & 2.346 & .020 (c) \\
\hline
\end{tabular}

The crossing between corruption propensity and the need to build oneself a house gives a coefficient contingency equal to 0.166 which translates a strong relationship between the two variables.

- Security Need

The results of random sorting have indicated to us that civil servants of education are in dissatisfaction and incapable to satisfy the security need. As such, to determine the significance of the link between the two variables, we have proceeded to a crossing as shown on the table below.

Table 2: Crossing between corruption propensity and need for security

Symmetric Measurement

\begin{tabular}{|l|l|r|c|c|c|}
\hline \multicolumn{2}{|l|}{} & Value & $\begin{array}{l}\text { Asymptomatic } \\
\text { standard error (a) }\end{array}$ & $\begin{array}{c}\text { T } \\
\text { approximate (b) }\end{array}$ & $\begin{array}{c}\text { Approximate } \\
\text { significance }\end{array}$ \\
\hline $\begin{array}{l}\text { Nominal by } \\
\text { Nominal }\end{array}$ & Coefficient of contingency & .094 & & & \\
\hline $\begin{array}{l}\text { Interval by } \\
\text { Interval }\end{array}$ & R of Pearson & -.007 & .076 & -.101 & .920 (c) \\
\hline $\begin{array}{l}\text { Ordinal by } \\
\text { Ordinal }\end{array}$ & $\begin{array}{l}\text { Correlation of } \\
\text { Spearman }\end{array}$ & .012 & .074 & .166 & .868 (c) \\
\hline \multicolumn{2}{|l|}{ Number of valid observations } & 192 & & & \\
\hline
\end{tabular}

It prevails from this symmetric measurement table that the coefficient of contingency is equal to 0.94 which translates a strong link between the two variables. 
-Need to eat and drink

Results of the table below indicate the link which exists between this modality and corruption propensity.

Table 3: Crossing between corruption propensity and need to eat and drink

Symmetric Measure

\begin{tabular}{|l|l|c|c|c|c|}
\hline \multicolumn{2}{|l|}{} & Value & $\begin{array}{l}\text { Asymptomatic } \\
\text { standard error (a) }\end{array}$ & $\begin{array}{c}\text { T } \\
\text { approximate (b) }\end{array}$ & $\begin{array}{c}\text { Approximate } \\
\text { significance }\end{array}$ \\
\hline $\begin{array}{l}\text { Nominal by } \\
\text { Nominal }\end{array}$ & $\begin{array}{l}\text { Coefficient of } \\
\text { contingency }\end{array}$ & .072 & & & .609 \\
\hline $\begin{array}{l}\text { Interval by } \\
\text { Interval }\end{array}$ & R of Pearson & .067 & .073 & .923 & .357 (c) \\
\hline $\begin{array}{l}\text { Ordinal by } \\
\text { Ordinal }\end{array}$ & $\begin{array}{l}\text { Correlation of } \\
\text { Spearman }\end{array}$ & .060 & .073 & .828 & .409 (c) \\
\hline \multicolumn{2}{|l|}{ Number of valid observations } & 192 & & & \\
\hline
\end{tabular}

The results of the above symmetric measurement table indicate a coefficient of contingency equal to 0.072 which translates a weak relationship between the two variables.

Definitely, looking at all these results, it is evident that the values of contingency coefficients translate a significant link between the different modalities and, consequently, a correlation between the two variables of our hypothesis. The practice of corruption is therefore a function of civil servants' dissatisfaction of needs. As well, there exists a significant link between the independent and dependent variables of our research hypothesis. That will be related to the fact that teachers accord a very positive valence to their primary and secondary needs whose dissatisfaction lead them to carry out actions devoid of ethics. In effect, to build oneself a house, have comfort, eat and drink at will are registered in their fantasy up to the point where it is difficult for them to get rid abruptly. Furthermore it is about primary and secondary needs which, in reality, should be satisfied to guarantee a good life balance to the individual. The dissatisfaction of needs push him to find tangential equations at times to solve his problems by carrying out actions such as swindle, favouritism and others to satisfy his needs.

\section{* Expectations}

To measure the relationship existing between the different variables and verify our research hypothesis, we have crossed the propensity of corruption practice with the expectations of Education civil servants. Considering the fact that the results of flat sorting having revealed to us that civil servants of education more and more expect a good salary, job security, promotions and premiums, we shall be interested here in crossing between these expectations and the propensity of corruption practice.

- $\quad$ To have a good salary

To have a good salary is one of the civil servants' of education expectations. As such to verify our hypothesis we have crossed this modality with the corruption propensity which gives us the below table.

Table 4: Crossing between corruption propensity and to have a good salary

Symmetric Measurements

\begin{tabular}{|l|l|c|c|c|c|}
\hline \multicolumn{2}{|l|}{} & & $\begin{array}{l}\text { Asymptomatic } \\
\text { standard error } \\
\text { (a) }\end{array}$ & $\begin{array}{c}\text { T } \\
\text { approximate } \\
\text { (b) }\end{array}$ & $\begin{array}{c}\text { Approximate } \\
\text { significance }\end{array}$ \\
\hline $\begin{array}{l}\text { Nominal by } \\
\text { Nominal }\end{array}$ & $\begin{array}{l}\text { Coefficient of } \\
\text { contingency }\end{array}$ & .069 & & & .633 \\
\hline $\begin{array}{l}\text { Interval by } \\
\text { Interval }\end{array}$ & R of Pearson & -.069 & .048 & -.954 & .341 (c) \\
\hline $\begin{array}{l}\text { Ordinal by } \\
\text { Ordinal }\end{array}$ & $\begin{array}{l}\text { Correlation of } \\
\text { Spearman }\end{array}$ & -.068 & .056 & -.936 & .350 (c) \\
\hline Number of valid observations & 192 & & & \\
\hline
\end{tabular}

It prevails from this symmetric measurement table that the contingency coefficient is equal to 0.069 . That (which) translates a weak link between the two variables.

- To have promotions

The results of the table below indicate the link which exists between this modality and the corruption propensity. 
Table 5: Crossing between corruption propensity and promotions. Symmetric Measurements

\begin{tabular}{|l|l|c|c|c|c|}
\hline \multicolumn{2}{|l|}{} & Value & $\begin{array}{c}\text { Asymptomatic } \\
\text { standard error } \\
\text { (a) }\end{array}$ & $\begin{array}{c}\text { T } \\
\text { approximate } \\
\text { (b) }\end{array}$ & $\begin{array}{c}\text { Approximate } \\
\text { significance }\end{array}$ \\
\hline $\begin{array}{l}\text { Nominal by } \\
\text { Nominal }\end{array}$ & $\begin{array}{l}\text { Coefficient of } \\
\text { contingency }\end{array}$ & .104 & & .350 \\
\hline $\begin{array}{l}\text { Interval by } \\
\text { Interval }\end{array}$ & R of Pearson & .055 & .072 & .758 & .449 (c) \\
\hline $\begin{array}{l}\text { Ordinal by } \\
\text { Ordinal }\end{array}$ & $\begin{array}{l}\text { Correlation of } \\
\text { Spearman }\end{array}$ & .072 & .072 & .994 & .321 (c) \\
\hline Number of valid observations & 192 & & & \\
\hline
\end{tabular}

The results of table 5 above indicates a contingency coefficient equal to 0.104 which translates a link between the two variables.

- To have premiums

The results of random sorting have indicated to us that civil servants of education give an important value to incentives. As such, to determine the significance of the link between the two variables, we have proceeded to a crossing. Where with the table below.

Table 6: Crossing between corruption propensity and to have premiums Symmetric Measurements

\begin{tabular}{|l|l|c|c|c|c|}
\hline \multicolumn{2}{|l|}{} & Value & $\begin{array}{l}\text { Asymptomatic } \\
\text { standard error } \\
\text { (a) }\end{array}$ & $\begin{array}{c}\text { T } \\
\text { approximate (b) }\end{array}$ & $\begin{array}{c}\text { Approximate } \\
\text { significance }\end{array}$ \\
\hline $\begin{array}{l}\text { Nominal by } \\
\text { Nominal }\end{array}$ & $\begin{array}{l}\text { Coefficient of } \\
\text { contingency }\end{array}$ & .156 & & & .092 \\
\hline $\begin{array}{l}\text { Interval by } \\
\text { Interval }\end{array}$ & R of Pearson & .157 & .074 & 2.186 & $.030(\mathrm{c})$ \\
\hline $\begin{array}{l}\text { Ordinal by } \\
\text { Ordinal }\end{array}$ & $\begin{array}{l}\text { Correlation of } \\
\text { Spearman }\end{array}$ & .157 & .073 & 2.192 & .030 (c) \\
\hline Number of valid observations & 192 & & & \\
\hline
\end{tabular}

It prevails from this table of symmetric measurement that the contingency coefficient is equal to 0.156 . Which translates a link between the two variables.

Definitely the results of the above symmetric measurement table translate a significant link between the different modalities of our variables. Consequently, the dissatisfaction of civil servants' expectations has an impact on corruption practice. From these crossings, it is evident that there exists a significant relationship between the different variables of our research hypothesis, which shows the accent carried by education civil servants on their expectations. In effect, these latest constitute the extrinsic factors of motivations. They are susceptible to stimulate individuals at their duty post. The acquisition of a premium following a good output for example constitutes a factor motivating the individual not only to more efforts but also to work more as possible within the respect of ethics.

In the specific framework of our study, the civil servants of education tired of a waiting for salary revalorization which is not coming since many years have found a loophole by the committing less in orthodox actions such as coining places in schools, services rendered in the treatment of files or even for appointments to posts of responsibility.

* Working conditions.

From the random sorting results, it reveals that education civil servants work in deplorable working conditions. The salary is low, incentives low and insufficient, taxes and charges are (elevated) high. The consequences of these working conditions according to the simple sorting is that they have an impact on corruption practice in the Cameroonian Public Service. Also, to establish the significance of this incidence, have we crossed these working conditions with the manifestations of corruption practice as noticed by the enquired persons notably the coining and favouritism.

- Very low salary

The very low level of education civil servants' salaries explains the intensification of corruptible practices according to the simple sorting. As such, to determine the significance of the link between the two variables of our research hypothesis, we have proceeded to a crossing. As the table below 
Table 7: Crossing between coining and very low salary. Symmetric Measurements

\begin{tabular}{|l|l|c|c|c|c|}
\hline \multicolumn{2}{|l|}{} & Value & $\begin{array}{c}\text { Asymptomatic } \\
\text { standard error } \\
\text { (a) }\end{array}$ & $\begin{array}{c}\text { T } \\
\text { approximate (b) }\end{array}$ & $\begin{array}{c}\text { Approximate } \\
\text { significance }\end{array}$ \\
\hline $\begin{array}{l}\text { Nominal by } \\
\text { Nominal }\end{array}$ & $\begin{array}{l}\text { Coefficient } \\
\text { contingency }\end{array}$ & .147 & & & .035 \\
\hline $\begin{array}{l}\text { Interval by } \\
\text { Interval }\end{array}$ & R of Pearson & .149 & .088 & 2.116 & .036 (c) \\
\hline $\begin{array}{l}\text { Ordinal by } \\
\text { Ordinal }\end{array}$ & $\begin{array}{l}\text { Correlation of } \\
\text { Spearman }\end{array}$ & .149 & .088 & 2.116 & .036 (c) \\
\hline Number of valid observations & 199 & & & \\
\hline
\end{tabular}

The results of the above symmetric measurement table indicate a contingency coefficient equal to 0.147 which translates a relationship between coining and very low salary.

As concerns crossing between favouritism and very low salary we have the table below.

Table 8: Crossing between favouritism and very low salary.

Symmetric Measurements

\begin{tabular}{|l|l|c|c|c|c|}
\hline \multicolumn{2}{|l|}{} & Value & $\begin{array}{c}\text { Asymptomatic } \\
\text { standard error } \\
\text { (a) }\end{array}$ & $\begin{array}{c}\text { T } \\
\text { approximate (b) }\end{array}$ & $\begin{array}{c}\text { Approximate } \\
\text { significance }\end{array}$ \\
\hline $\begin{array}{l}\text { Nominal by } \\
\text { Nominal }\end{array}$ & Coefficient of contingency & .043 & & & .545 \\
\hline $\begin{array}{l}\text { Interval by } \\
\text { Interval }\end{array}$ & R of Pearson & -.043 & .069 & -.604 & .547 (c) \\
\hline $\begin{array}{l}\text { Ordinal by } \\
\text { Ordinal }\end{array}$ & $\begin{array}{l}\text { Correlation of } \\
\text { Spearman }\end{array}$ & -.043 & .069 & -.604 & .547 (c) \\
\hline Number of valid observations & 199 & & & \\
\hline
\end{tabular}

It shows from this symmetric measurements table that the contingency coefficient is equal to 0.043 .wWhich translates a link between the two variables.

Definitely it appears that in tables 7 and 8 the contingency coefficient of values 0.147 and 0.043 signify a link between the different modalities. Where in a correlation between working conditions and corruption practice. From these crossings we notice that the link between the modalities is significant and consequently the one between the two variables of research hypothesis.

This link comes from the fact that civil servant teachers put a particular accent on their working conditions. In all, from all the crossings, comes a strong link between psychological motivations of education civil servants and corruption practice in the Cameroon Public Service. Needs working conditions passing through the expectations of education civil servants, the impact on the practice of corruption is important. The priority needs of civil servants of education (build oneself a house, to eat and drink, to be in security, to have comfort), as well as their expectations (a good salary, job security, promotions, incentives) are not satisfied. More so they live in pitiful working conditions (very low salaries, more and more absence of service, insufficient incentives, excessive taxes and charges). This will be the cause and even the origin of the propping of corruption practice. In effect, the weak level of salary or absence of incentives might explain that education civil servants have opted for favouritism or coining of their services in order to round up their month end or, as they say it themselves, join the two ends, survive.

\section{V- DISCUSSION}

Our study is situated in a correlational perspective. The effect here is the practice of corruption. In effect, we wish to detect the origin of corruption practice in the Cameroon public service notably in the Ministries of Basic education and Secondary education. After the analysis and verification of data collected from civil servant teachers, we (noticed) realized that they give a big importance to their psycho-sociological motivations, which according to them constitute the source and origin of corruption in their Ministries.

The question we ask ourselves is to know if beyond the dissatisfaction of needs, of expectations or poor working conditions of civil servant teachers' corruption practice would not be explain by other mobiles. Does corruption in Cameroon in general and in the education sector not also come from a mode or mentality phenomenon? For how does one understand the attitude of those of education civil servants who, although being under the shelter of need due to the advantages their posts of responsibility provide them, put up such acts again? In response, we advance that it is a question of mentality, mode being that the appointment post representing drinking trough that has to be emptied very soon as possible for fear of being ejected without having realized 
something; since post is not an occupant's house and appointment belongs to the state.

Looking at the results of our enquiry, it appears that the link between corruption practice and psychosociological motivations is really tiny. But, can one not also apprehend the phenomenon as a sort of mimesis.

In effect, today Cameroon is populated with a race of "new rich men" who come from nowhere and dictate their laws. One even finds them as far as the National Assembly. And because man is changing and diverse, changing and mobile ends up getting used to and take the color of the environment in which he evolves. It is such that beyond the dissatisfaction of needs or expectations, education civil servants in the question of well-being and conservation of his image, creates corruption poles susceptible of regenerating money at his level necessary for his survival just to talk like them-selves elsewhere we have assumptions such as:

- The individual is first preoccupied by himself from his birth up to death.

- The individual seeks to satisfy his needs and his objectives before those of the organization.

- The individual wants to work in a pleasant sociable environment and, paradoxically, satisfy, within possible means his need to be alone.

As such, if we stop at the level of these postulates, we easily note of this spirit of egocentrism which likes every individual. While the state fights for the satisfaction of the interest of all, the individual due to his nature fights for his / her proper interests. Making them pass before common interests. So, this, far from contradicting the results of the enquiry, constitutes a limit. For although the education civil servant has unsatisfied needs and expectations, he is also egocentric by nature and that is what might also justify the fact that although being under the shelter of need, it will always be tempted to carry out less orthodox actions.

\section{CONCLUSION}

The object of our study consisted of establishing a correlation between psycho-sociological motivations of civil servants and corruption practice in the Cameroon Public Service. To arrive at that, we have emitted the hypothesis that psycho-sociological motivations of civil servants have an impact on the practice of corruption in the Cameroon Public Service. At the moment that it is ending and especially looking at the exploration of the results of our enquiry, and of consequent deductions, it prevails that the dissatisfaction of Primary and Secondary needs of civil servants has an impact on the level of corruption in the Cameroonian Public Service is linked to the dissatisfaction of expectations of civil servants. At last, the working conditions of civil servants who are demotivated have an influence on corruption practice in the Cameroonian Public Service. Concerning the case analyzed, the Cameroon Government ought to, in view to palliate the phenomenon, take dispositions such as increase of salaries, the end of impunity, the sensitization of the masses on the mishaps of the ill, the teaching of patriotism and of merit to citizens, the inculcation of effort to children.

\section{QUESTIONAIRE}

This question which is treated in strict confidentiality has as goal to establish a correlation between psychosociological motivations of civil servants and corruption practice in the Cameroon Public Service.

\section{I - IDENTIFICATION}

$\mathrm{N}^{\circ}$

Q1. Sex: Man

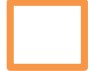

Woman

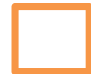

Q2. In which age range do you belong?

(20-30 years), (30-40 years), (40-50 years), (50-60 years)

Q3. Ethnic:

Q4. Religious believe: Protestant

Q5. Matrimonial status: married

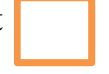

Q6. Socio-professional status:

Q7. To which salary scale do you belong?
(100 000-120 000),
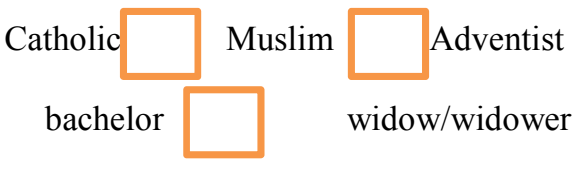

widow/widower
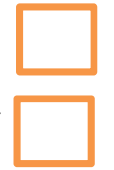

(80-100 000)

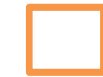

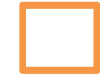

(120 000-140 000),
(140 000-160 000) 
Q8. Level of studies:

\section{II- GENERAL INFORMATIONS}

Q9. What do you think about corruption?

Q10. Have you ever been confronted with a corruption situation?

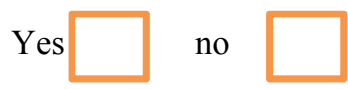

Q11. If yes in which position were you?

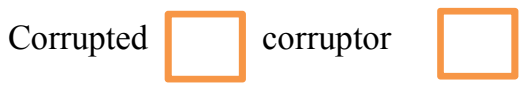

Q12. Do you do it regularly?

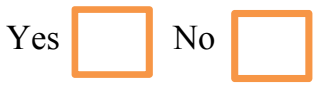

Why?

\section{III-MOTIVATIONS OF CORRUPTION PRACTICE}

Q13. According to you what are, the causes of the putting in place of corruption practice in Cameroon Public Service notably:

At Basic Education and at Secondary Education? Unsatisfied needs

Bad working conditions Unsatisfactory expectations

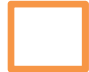

Others:

Q14. What are the prime needs of education civil servants?

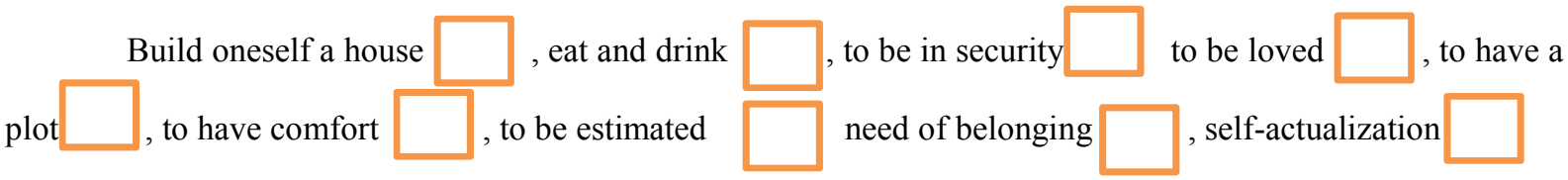

Q15. Who are those who are satisfied?

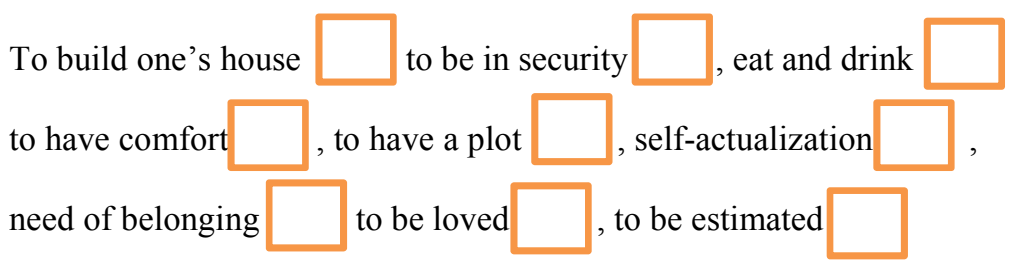

Q16. Do these needs have an impact on corruption practice?

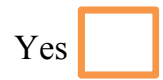

No

Q17. What is this impact?

$$
\text { - favour corruption }
$$

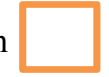
- inhibit corruption

Q18. What are the expectations of education civil servants?

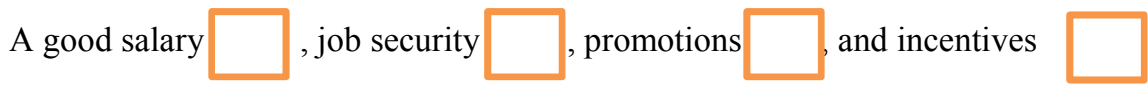


Others:

Q19. Who are those who are satisfied?

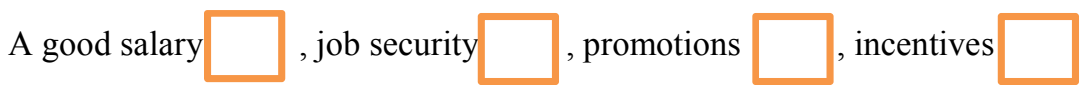

Q20. Do they have an effect on the corruption system?

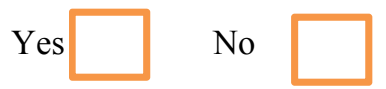

Why?

Q21. In which working conditions does an education civil servant had to find himself?

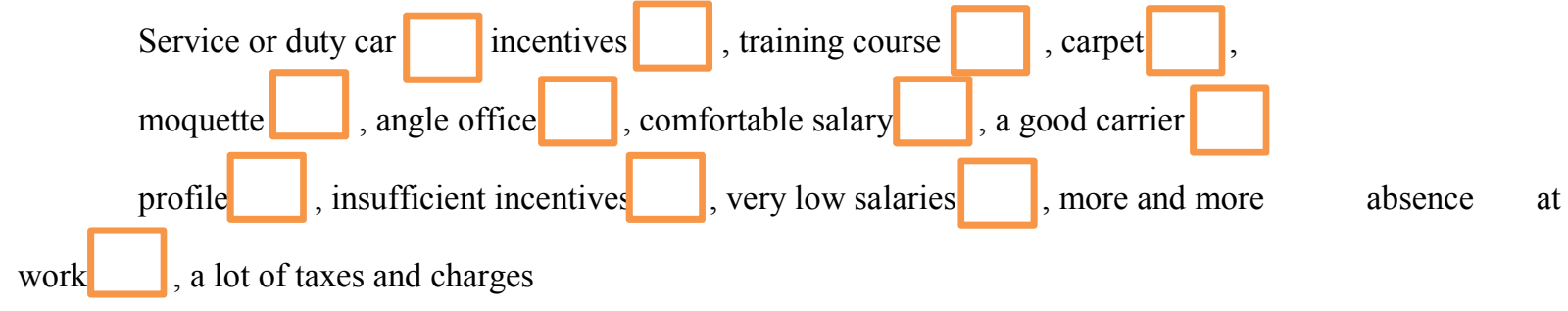

Q22. In which working conditions are they?

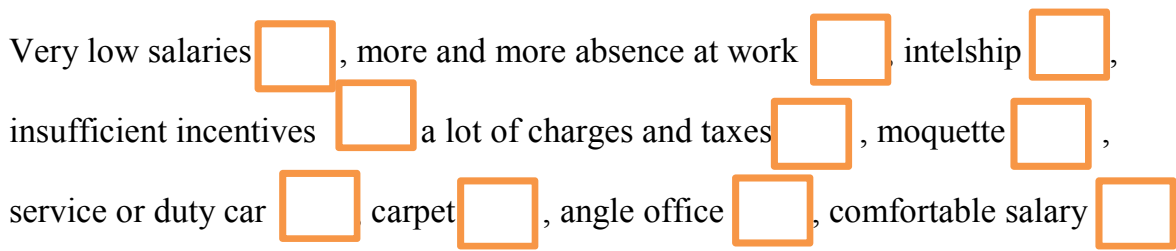

Q23. What is the effect of the working conditions on the corruption system?

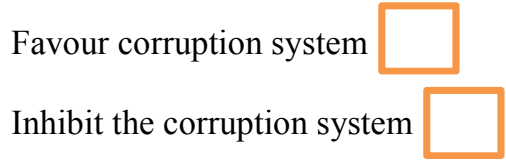

Q24. What is the propensity of corruption in your Ministry of origin?

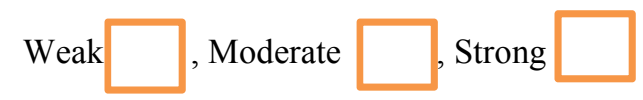

Q25. What is the reason?

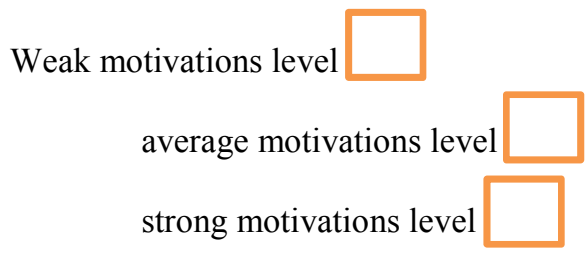

Q26. Under which forms do they manifest?

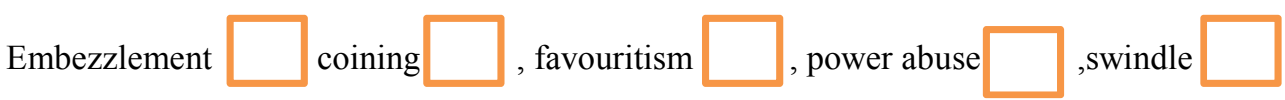

\section{BIBLIOGRAPHICAL REFERENCES}

Ayissi, L. (2003). Corruption and Governance. Yaoundé, PUY.

Amblard, H. and al. (1987). Management of human resources. Eyrolles

BIDIAS, B. (1971). Public finances and the financial economy of the Federal Republic of Cameroon. First edition Chauchard, C.J.L. (1989). Precise of personnel management and human resources. The editions of organization, Paris: France. 
Citeau, J.-P. and engelhardt-bitrian, B. (1999), Introduction to psycho-sociology, Paris: Armand Colin.

Grawitz, M. (1976). Lexical of social sciences. Paris: Dalloz.

Hellriegel, D., and al. (1999), Management of organizations. Paris: New horizons.

Hertzberg, F., and al. (1959). The motivation to work.New York: Wiley.

Jacquement, N. (2006). Micro-economy of corruption. In: French review of economy, Volume 20, nº 4 , pp.117159.

Klttgaard, R. (1988). Controlling corruption. Berkley (CA): University of California press.

Maslow, H.A. (1954), Motivation and personality, New York, Harper and Row.

Matalon, B. (1999), experimenting and observing «psychology notes», Paris, Dunod.

Muchelli, A., cited by Citeau, J.-P. and Engelhardt-bitrian, B. (1999), Introduction to psycho-sociology. Paris: Armand Colin.

Nkelzok Komtsindi, V. (2004). corruption: a systematical interpretation, Paris, Dianoïa: PUF.

Nuttin, J. (1963). Motivation, in «treaty of Fraise and Piaget», Paris, PUF, pp.1-73. (1980). Theory of human motivation: from need to project of action. Paris, PUF. (1985). Theory of human motivation, Paris, PUF, $2^{\text {nd }}$ edition.

Peter Ulrich, cited by Christoph Stuckel-Berger (1998), «Fight against corruption», Reference 1/100. Lausanne, 2000 .

Pieron, H. (1992). Vocabulary of psychology, Paris: PUF.

Redheuil ,N. (1990). Remuneration-performance relationship. Dissertation of DEA in Science of management. University of Bordeaux.

Rousse, p. (2000). «Motivation at work concepts and theories», Note ${ }^{\circ} 326$, Lirhe, Toulouse: October.

Mutations $\mathrm{N}^{\circ} 396$, of Tuesday $03^{\text {rd }}$ October 2000

$\mathrm{N}^{\circ} 1290$, of Tuesday $30^{\text {th }}$ November 2004.

Transparency International Cameroon, «News Letter», N004, December 2004. 